\title{
EFFECT OF COMPOST AND SOME BIO-STIMULANT TREATMENTS ON: B. ESSENTIAL OIL PRODUCTION AND SOME CHEMICAL CONSTITUENTS OF CUMIN
}

\author{
M.A.H. Abdou; M.K. Aly; A.A. El-Sayed; E.T. Ahmed and T.A. Helmy \\ Hort. Dept., Fac. Agric., Minia Univ., Egypt.
}

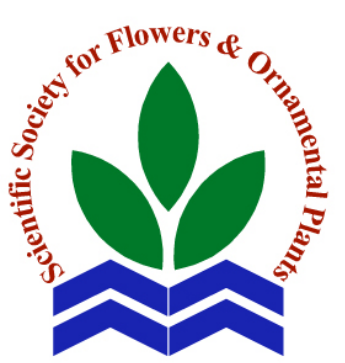

Scientific J. Flowers \& Ornamental Plants, 2(3):237-248 (2015).

Received: $15 / 10 / 2015$

Revised by: Prof. Dr. M.S. Hanafy, Cairo Univ.

ABSTRACT: A field experiment was carried out at the experimental farm of Fac. of Agric., Minia Univ. during two seasons (2012/2013 and $2013 / 2014)$ to study the effect of compost $(0,2.5,5$ and 7.5 ton/fed) and eight bio-stimulants treatments salicylic acid (Sal.) at 100 and $200 \mathrm{ppm}$, ascorbic acid (Asc.) at 100 and $200 \mathrm{ppm}$, active yeast at 5 and $10 \mathrm{~g} / \mathrm{l}$, vitamin $\mathrm{E}$ at 50 and $100 \mathrm{ppm}$ and control) on oil production and chemical constituents of cumin plants. The data indicated that using compost at 7.5 ton/fed significantly increased essential oil production parameters, photosynthetic pigments contents and $\mathrm{N}, \mathrm{P}$ and $\mathrm{K} \%$ comparing with other treatments. Also, data showed that all eight used treatments of bio-stimulants significantly increased essential oil production (oil \%, oil yield/plant and /fed) and chemical constituents (pigments and $\mathrm{N}, \mathrm{P}$ and $\mathrm{K} \%$ ) as compared with control in both seasons, except, vit. E (50 ppm) in the second season for chlorophyll ( $\mathrm{a}$ and $\mathrm{b}$ ) and carotenoids, as well as, active yeast $(5 \mathrm{~g} / \mathrm{l})$ for chlorophyll a in both season and phosphorus \% in the first season. The best treatments were Sal. and Asc. at the rate of $200 \mathrm{ppm}$ in most cases and vit. E (100 ppm) and active yeast (10 g/l) in some cases, Prof. Dr. A.M. Hammouda, especially chemical constituents.

Hort. Res. Inst., ARC.

Key words: Cumin, compost, salicylic acid, ascorbic acid, vitamin E and active yeast.

\section{INTRODUCTION}

Cumin (Cuminum cyminum, L.) is an annual herb, belonging to Family Apiaceae (umbellifera). Cumin is primarily grown for its fruits, commercially called seeds. Cumin seeds have medical applications and contain $7 \%$ essential oil, $13 \%$ resin, 2.5 to $4 \%$ essence and aleurone (Saeidnezhad and Rezvani-Moghadum, 2009).

Application of organic fertilizer is increased essential oil yield and chemical constituents of cumin as reported by Safwat and Badran (2002); Badran et al. (2007); Asl and Moosavi (2012); Asgharipour and Sirousmehr (2012); Seghatoleslami (2013); Patel et al. (2013) and Forouzandeh et al. (2014).
Some bio-stimulants i.e. ascorbic acid, alpha-tocopherol, salicylic acid and dry yeast improve plant growth and its production. Ascorbic acid, salicylic acid, alphatocopherol (vit. E) have synergistic effect on growth and productivity of most medical and aromatic plants. Al-Shareif (2006) and Botros (2013) on caraway, Ayat (2007) and Rekaby (2013) on coriander and Tanious (2008) and Hendawy and Ezz El-Din (2010) on fennel showed that foliar spray of ascorbic acid increased essential oil \% and yield. Al-Shewailly (2012), Rahimi et al. (2013) on cumin, Abdou et al. (2009) and Shala (2012) on caraway, Hassan and Ali (2010) and Rekaby (2013) on coriander mentioned that salicylic acid promoted all essential oil aspects (oil \%, oil yield/plant and /fed), as well as, pigments and NPK 
elements percentages. Ismail (2008) on black cumin and Botros (2013) on caraway found that essential oil \% and oil yield/plant and /fed, as well as, pigments chlorophyll (a and b) and carotenoids contents) and percentages of $\mathrm{N}, \mathrm{P}$ and $\mathrm{K}$ were considerably increased due to the treatment of vit. $\mathrm{E}$.

It is known that yeast is considered as a natural source of cytokinins that stimulate cell division and enlargement, as well as, the synthesis of proteins, nucleic acids and chlorophyll that reflected in growth and production of plants (Fathy and Farid, 1996). Foliar application of yeast increased essential oil \% and yield, as well as, chlorophylls and N, P and K \% of many plants such as, anise plants (Hemdan, 2008), black cumin (Ismail, 2008), caraway (Botros, 2013) and coriander (Rekaby, 2013).

The aim of this study was to investigate the effect of compost and bio-stimulants (ascorbic acid, salicylic acid, vit. E and yeast) on essential oil production and some chemical constituents of cumin.

\section{MATERIALS AND METHODS}

This field experiment was carried out during the two successive seasons of 2012/2013 and 2013/2014 at the Experimental Farm, Fac. of Agric., Minia Univ.

The experiment designed in a randomized complete block design in a split plot arrangement with three replicates. The main plots (A) included four levels of compost $(0,2.5,5$ and 7.5 ton/fed), while nine treatments (salicylic acid at 100 and 200 ppm, ascorbic acid at 100 and 200 ppm, vit. $\mathrm{E}$ at 50 and $100 \mathrm{ppm}$, active yeast (Saccharomyces cerevisiae) at 5 and $10 \mathrm{~g} / 1$ in addition to control) occupied the sub plots (B), therefore, the interaction treatments $(A \times B)$ were 36 treatments.

The fruits of cumin were sown on October, $5^{\text {th }}$ in both seasons. The experimental unit (plot) was $3 \times 3 \mathrm{~m}$ and containing 4 rows, $60 \mathrm{~cm}$ apart and seeds were cultivated in hills, $25 \mathrm{~cm}$ apart, therefore plot contained 48 hills and plant were thinned to two plants/hill after 5 weeks from sowing date. The physical and chemical analysis of the used soil is shown in Table (a).

Compost (called El-Neel compost) was obtained from the Egyptian company for solid waste utilization, El-Minia El-Gdeda City. This compost was added during preparing the soil to cultivation in both seasons. The physical and chemical analysis of the used compost were shown in Table (b)

Salicylic acid, ascorbic acid, vit. E and active yeast (Saccharomyces cerevisiae) were applied as foliar spray twice for each season; the first spray was applied after 38 days from sowing date and one month thereafter in both seasons. All other agricultural practices were carried out as usual in the two seasons.

Table a. Physical and chemical analysis of the experimental soil.

\begin{tabular}{|c|c|c|c|}
\hline Soil Character & Value & Soil Character & Value \\
\hline Sand \% & 27.20 & Available $\mathbf{P} \%$ & 15.12 \\
\hline Silt \% & 30.70 & Exch. $K^{+}$(mg/100 g soil) & 2.11 \\
\hline Clay \% & 42.10 & Exch. $\mathrm{Ca}^{++}(\mathrm{mg} / 100 \mathrm{~g}$ soil $)$ & 31.74 \\
\hline Soil type & Clayey loam & Exch. $\mathrm{Na}^{+}$(mg/100 g soil) & 2.40 \\
\hline Organic matter \% & 1.65 & \multirow{5}{*}{$\begin{array}{l}\text { DTPA } \\
\text { Ext. ppm }\end{array}$} & 8.34 \\
\hline $\mathrm{CaCO}_{3} \%$ & 2.09 & & 2.06 \\
\hline E.C. $(\mathrm{mmhos} / \mathrm{cm})$ & 1.04 & & 2.71 \\
\hline pH (1:2.5) & 7.82 & & 8.16 \\
\hline Total N \% & 0.08 & & \\
\hline
\end{tabular}


Table b. Physical and chemical properties of the used compost.

\begin{tabular}{lclc}
\hline Properties & Values & Properties & Values \\
\hline Dry weight of $\mathbf{1} \mathbf{~ m}^{\mathbf{3}}$ & $450 \mathrm{~kg}$ & $\mathbf{C} / \mathbf{N}$ ratio & $14.1-18.5$ \\
Fresh weight of $\mathbf{1} \mathbf{~ m}^{\mathbf{3}}$ & $650-700 \mathrm{~kg}$ & $\mathbf{N a C l} \%$ & $1.1-1.75$ \\
Moisture (\%) & $25-30$ & Total P \% & $0.5-0.75$ \\
pH (1:10) & $7.5-8$ & Total K \% & $0.8-1.0$ \\
E.C. $(\mathbf{m}$ mhose/cm) & $2-4$ & Fe ppm & $150-200$ \\
Total N \% & $1-1.4$ & Mn ppm & 25.56 \\
Org. matter \% & $32-34$ & $\mathbf{C u ~ p p m ~}$ & $75-150$ \\
Org. carbon \% & $18.5-19.7$ & $\mathbf{Z n ~ p p m}$ & $150-225$ \\
\hline
\end{tabular}

Plants were harvested in the mature stage at the second week of April in both seasons.

\section{Data were recorded as follows:}

\section{1- Essential oil production:}

Oil percentage was determined according to British Pharmacopoeia, 1963. Also, oil yield/plant (ml/plant) and oil yield/fed (liter/fed) was calculated.

\section{2- Chemical composition:}

\section{a. Photosynthetic pigments:}

Chlorophyll (a and b) and carotenoids were extracted by N-N dimethyl-formamide according to Moran (1982) using the spectrophotometer at wavelength of 656 , $665,452.5 \mu \mathrm{m}$, respectively then calculated using the following equations:

Chl. $\mathrm{a}=(16.5 \times \mathrm{E} \mathrm{665)}-(8.3 \times \mathrm{E} 656)=$ $\ldots \ldots . . \times 1000 / 0.5=\ldots \ldots . \mathrm{mg} / \mathrm{g}$.

Chl. $\mathrm{b}=(33.3 \times \mathrm{E} 656)+(12.5 \times \mathrm{E} 665)=$ $\ldots \ldots . . \times 1000 / 0.5=\ldots \ldots . \mathrm{mg} / \mathrm{g}$.

Carot. $=(4.2 \times \mathrm{E} 452.5)-(0.264 \times$ Chl. $\mathrm{a}-$ $0.496 \times$ Chl. b) $=\ldots \ldots \times 1000 / 0.5=\ldots \ldots$. $\mathrm{mg} / \mathrm{g}$.

$\mathrm{E}=$ Optical density at given wavelength .

\section{b. $\mathbf{N}, \mathbf{P}$ and $\mathrm{K}$ determinations:}

- Nitrogen percentage was determined by using the modified micro-kjeldahl method as described by Wilde et al. (1985).
- Phosphorus percentage was determined by the spectrophotometer at wavelength of $650 \mu \mathrm{m}$ according to the method of Chapman and Pratt (1975).

- Potassium percentage was estimated using flame-photometer method according to Cottenie et al. (1982).

The data of the two seasons were subjected to the statistical analysis of variance MSTAT-C (1986) and L.S.D test at 0.05 was used to compare the average means of treatments.

\section{RESULTS AND DISCUSSION}

\section{1- Essential oil production:}

\section{a. Essential oil \%:}

Obtained data in Table (1), indicated that essential oil \% was significantly increased due to all compost fertilization levels in both seasons over those of the control. The highest essential oil percentages (5.05 and $5.75 \%$ in both seasons) were obtained with compost at 7.5 ton/fed. Regarding the effect of eight bio-stimulant treatments, all used treatments significantly increased essential oil \% in comparison with control plants, in both seasons, except, the treatment of Sal. at $100 \mathrm{ppm}$ in the first season. The highest values were obtained due to the use of Sal. or Asc., each at $200 \mathrm{ppm}$. The interaction between compost and bio-stimulant treatments was significant for essential oil \% in both seasons. The highest essential oil \% 
Table 1. Effect of compost, salicylic acid, ascorbic acid, active yeast and vitamin $E$ on essential oil percentage, essential oil yield/plant and /fed of Cuminum cyminum, L., at the first and second seasons.

\begin{tabular}{|c|c|c|c|c|c|c|c|c|c|c|}
\hline \multirow{3}{*}{$\begin{array}{l}\text { Bio-stimulant } \\
\text { treatments (B) }\end{array}$} & \multicolumn{10}{|c|}{ Compost levels (ton/fed) (A) } \\
\hline & \multicolumn{5}{|c|}{$1^{\text {st }}$ season $(2012 / 2013)$} & \multicolumn{5}{|c|}{$2^{\text {nd }} \operatorname{season}(2013 / 2014)$} \\
\hline & 0.0 & 2.5 & 5.0 & 7.5 & $\begin{array}{c}\text { Mean } \\
\text { (B) }\end{array}$ & 0.0 & 2.5 & 5.0 & 7.5 & $\begin{array}{c}\text { Mean } \\
\text { (B) }\end{array}$ \\
\hline \multicolumn{11}{|c|}{ Essential oil percentage } \\
\hline Control & 2.90 & 3.63 & 3.83 & 4.57 & 3.73 & 2.96 & 4.06 & 4.63 & 4.88 & 4.13 \\
\hline Sal. at 100 ppm & 3.17 & 3.87 & 4.10 & 4.73 & 3.97 & 3.37 & 4.50 & 4.97 & 5.97 & 4.70 \\
\hline Sal. at 200 ppm & 3.87 & 4.17 & 4.83 & 5.37 & 4.56 & 4.07 & 4.20 & 5.63 & 6.20 & 5.03 \\
\hline Asc. at 100 ppm & 3.73 & 3.80 & 4.20 & 5.03 & 4.19 & 3.73 & 4.00 & 5.03 & 5.83 & 4.65 \\
\hline Asc. at 200 ppm & 3.83 & 4.20 & 4.77 & 5.30 & 4.53 & 4.00 & 4.63 & 5.67 & 6.50 & 5.20 \\
\hline Active yeast at $5 \mathrm{~g} / \mathrm{l}$ & 3.43 & 3.67 & 4.13 & 5.03 & 4.07 & 3.23 & 4.20 & 5.07 & 5.40 & 4.48 \\
\hline Active yeast at $10 \mathrm{~g} / \mathrm{l}$ & 3.73 & 3.77 & 4.17 & 5.20 & 4.22 & 3.70 & 4.27 & 4.87 & 5.60 & 4.61 \\
\hline Vit. E at 50 ppm & 3.57 & 3.73 & 4.07 & 5.03 & 4.10 & 3.20 & 4.40 & 4.80 & 5.60 & 4.50 \\
\hline Vit. E at 100 ppm & 3.67 & 3.87 & 4.20 & 5.17 & 4.23 & 3.60 & 4.23 & 4.93 & 5.73 & 4.62 \\
\hline Mean (A) & 3.54 & 3.86 & 4.26 & 5.05 & & 3.54 & 4.28 & 5.07 & 5.75 & \\
\hline L.S.D. at $5 \%$ & \multicolumn{2}{|c|}{$\mathrm{A}=0.27$} & $\mathrm{~B}=0.25$ & \multicolumn{2}{|c|}{$\mathrm{AB}=0.50$} & \multicolumn{2}{|l|}{$\mathrm{A}=0.22$} & $\mathrm{~B}=0.33$ & \multicolumn{2}{|c|}{$\mathrm{AB}=0.66$} \\
\hline \multicolumn{11}{|c|}{ Essential oil yield /plant (ml/plant) } \\
\hline Control & 0.20 & 0.28 & 0.34 & 0.46 & 0.31 & 0.21 & 0.30 & 0.45 & 0.62 & 0.38 \\
\hline Sal. at $100 \mathrm{ppm}$ & 0.25 & 0.33 & 0.41 & 0.62 & 0.39 & 0.32 & 0.47 & 0.56 & 0.87 & 0.54 \\
\hline Sal. at 200 ppm & 0.41 & 0.48 & 0.62 & 0.81 & 0.57 & 0.48 & 0.50 & 0.74 & 0.94 & 0.65 \\
\hline Asc. at $100 \mathrm{ppm}$ & 0.33 & 0.38 & 0.39 & 0.65 & 0.43 & 0.37 & 0.41 & 0.53 & 0.72 & 0.50 \\
\hline Asc. at 200 ppm & 0.42 & 0.49 & 0.57 & 0.67 & 0.54 & 0.46 & 0.54 & 0.68 & 0.92 & 0.64 \\
\hline Active yeast at $5 \mathrm{~g} / \mathrm{l}$ & 0.32 & 0.36 & 0.44 & 0.59 & 0.42 & 0.34 & 0.46 & 0.56 & 0.78 & 0.53 \\
\hline Active yeast at $10 \mathrm{~g} / \mathrm{l}$ & 0.38 & 0.39 & 0.45 & 0.61 & 0.45 & 0.40 & 0.50 & 0.62 & 0.82 & 0.57 \\
\hline Vit. E at 50 ppm & 0.31 & 0.41 & 0.45 & 0.59 & 0.43 & 0.33 & 0.51 & 0.58 & 0.71 & 0.52 \\
\hline Vit. E at 100 ppm & 0.34 & 0.41 & 0.46 & 0.64 & 0.46 & 0.38 & 0.50 & 0.60 & 0.84 & 0.57 \\
\hline Mean (A) & 0.33 & 0.39 & 0.45 & 0.63 & & 0.36 & 0.46 & 0.59 & 0.80 & \\
\hline L.S.D. at $5 \%$ & \multicolumn{2}{|c|}{$A=0.02$} & $\mathrm{~B}=0.01$ & \multicolumn{2}{|c|}{$\mathrm{AB}=0.02$} & \multicolumn{2}{|l|}{$A=0.02$} & $\mathrm{~B}=0.02$ & \multicolumn{2}{|c|}{$\mathrm{AB}=0.04$} \\
\hline \multicolumn{11}{|c|}{ Essential oil yield /fed (liter/fed) } \\
\hline Control & 8.61 & 11.83 & 14.51 & 19.65 & 13.35 & 8.99 & 12.82 & 19.04 & 26.48 & 16.26 \\
\hline Sal. at 100 ppm & 10.75 & 13.94 & 17.35 & 26.62 & 16.72 & 13.80 & 20.12 & 23.69 & 37.19 & 22.99 \\
\hline Sal. at 200 ppm & 17.57 & 20.28 & 26.30 & 34.37 & 24.22 & 20.42 & 21.36 & 31.61 & 40.10 & 27.87 \\
\hline Asc. at 100 ppm & 13.89 & 16.33 & 16.70 & 27.64 & 18.32 & 15.91 & 17.41 & 22.43 & 30.65 & 21.30 \\
\hline Asc. at 200 ppm & 18.11 & 20.86 & 24.26 & 28.76 & 22.88 & 19.80 & 23.07 & 29.13 & 39.41 & 27.47 \\
\hline Active yeast at $5 \mathrm{~g} / \mathrm{l}$ & 13.71 & 15.16 & 18.82 & 25.22 & 18.01 & 14.66 & 19.43 & 24.05 & 33.11 & 22.42 \\
\hline Active yeast at $10 \mathrm{~g} / \mathrm{l}$ & 16.17 & 16.73 & 19.02 & 25.94 & 19.34 & 16.86 & 21.15 & 26.51 & 35.17 & 24.47 \\
\hline Vit. E at 50 ppm & 13.28 & 17.32 & 19.03 & 25.13 & 18.49 & 13.98 & 21.96 & 24.82 & 30.46 & 22.21 \\
\hline Vit. E at 100 ppm & 14.66 & 17.59 & 19.57 & 27.51 & 19.58 & 16.34 & 21.44 & 25.75 & 35.77 & 24.36 \\
\hline Mean (A) & 13.93 & 16.62 & 19.39 & 26.70 & & 15.48 & 19.71 & 25.14 & 34.17 & \\
\hline L.S.D. at $5 \%$ & \multicolumn{2}{|c|}{$\mathrm{A}=0.72$} & $\mathrm{~B}=0.62$ & \multicolumn{2}{|c|}{$\mathrm{AB}=1.24$} & $A=0.96$ & & $B=0.96$ & \multicolumn{2}{|c|}{$\mathrm{AB}=1.92$} \\
\hline
\end{tabular}

Sal. : Salicylic acid Asc. : Ascorbic acid Vit. E : Vitamin E 
was obtained due to compost ( 7.5 ton/fed) in combination with Sal. or Asc. at the rate of 200 ppm.

\section{b. Essential oil yield/plant and/fed:}

Essential oil yield per plant and per fed were significantly increased due to the used of compost at three levels $(2.5,5$ and 7.5 ton/fed) in both seasons over those of the control Table (1). The increase in essential oil yield/fed due to these three compost treatments came to $19.31,39.20$ and $91.67 \%$ in the first season and 27.33, 62.40 and $120.74 \%$ in the second season, respectively compare to those of control. The presence of compost in soil may increase the secondary metabolites and quality of the product (Marculesuca et al., 2002). Similar results were obtained by Amin and Abdel Wahab (1999), Safwat and Badran (2002), Badran et al. (2007), Asgharipour and Sirousmehr (2012), Seghatoleslami (2013) and Patel et al. (2013) on cumin.

The results presented in Table (1) showed that all eight treatments remarkably induced essential oil yield/plant and /fed in both seasons. The best results were obtained with the use of Sal. and Asc. at 200 ppm treatments without significant differences between such two superior treatments in the second season. Salicylic and ascorbic acids are considered as auxinic action, since they have synergistic effect on productivity of medicinal and aromatic plants. In addition, the positive action of antioxidants in catching or chelating the free radicals which could result in extending the shelf life of plant cells and stimulate growth and production aspects (Rao et al., 2000 and Ozeker, 2005). The effect of salicylic acid in promoting essential oil \% and yield was emphasized by many authors such as Shala (2012) on caraway, Al-Shareif (2012) on black cumin and Badran et al. (2013) on coriander.

The interaction between compost and bio-stimulant treatments was significant for oil yield/plant and /fed in both seasons. The best interaction was compost $(7.5$ ton/fed $) \times$
Sal. at $200 \mathrm{ppm}$ in the first season and compost $(7.5$ ton/fed $) \times$ Sal. $(200 \mathrm{ppm})$ or Asc. $(200 \mathrm{ppm})$ in the second season (Table $1)$.

\section{2- Chemical composition:}

\section{a. Photosynthetic pigments:}

Data presented in Table (2) indicated that the three levels of compost $(2.5,5$ and 7.5 ton/fed) significantly promoted chlorophyll $\mathrm{a}, \mathrm{b}$ and carotenoids contents in both seasons with compared the control, except low level of compost for chlorophyll $b$ in the first season. The highest overall values, for the three pigments, in both seasons were given by compost at 7.5 ton/fed. The compost contains chelated micronutrients for easy plant absorption that reflect on modified morphological and physiological characteristics of plants and enhance chloroplast differentiation chlorophyll biosynthesis (Hendawy, 2008). Similar results were obtained by Shalatet (2006) on cumin, Hemdan (2008) on anise and Marzok (2011) on clove basil.

Concerning on bio-stimulant treatments, the used eight treatments significantly increased chlorophyll (a and b) and carotenoids contents, in both seasons, comparing to control, except, vit. E (50 ppm) in the second season for chlorophyll a and carotenoids in both seasons, as well as, active yeast $(5 \mathrm{~g} / \mathrm{l})$ and Asc. (100 ppm) for Chl. a in the first season (Table 2). Concerning on the contents of chlorophyll a, the treatments of Sal. (200 ppm) followed by Asc. $(200 \mathrm{ppm})$ then active yeast $(10 \mathrm{~g} / \mathrm{l})$ gave the highest contents of chl. a in the first season, while of vit. E (100 ppm) followed by yeast $(10 \mathrm{~g} / \mathrm{l})$ resulted in the highest chl. a in the second season. Regarding to the contents of chlorophyll $b$, the highest values were obtained with Asc. (200 ppm) followed by Sal. $(200 \mathrm{ppm})$ then yeast $(10 \mathrm{~g} / \mathrm{l})$ during the first season, while the treatments of Sal. (200 ppm) followed by active yeast $(10 \mathrm{~g} / \mathrm{l})$ gave the highest values in the second season. Also, the treatments of Asc. (200 ppm) in both seasons followed by Sal. (200 ppm) in 
Table 2. Effect of compost, salicylic acid, ascorbic acid, active yeast and vitamin $\mathbf{E}$ on chlorophyll a, b and carotenoids of Cuminum cyminum, L., at the first and second seasons.

\begin{tabular}{|c|c|c|c|c|c|c|c|c|c|c|}
\hline \multirow{3}{*}{$\begin{array}{l}\text { Bio-stimulant } \\
\text { treatments (B) }\end{array}$} & \multicolumn{10}{|c|}{ Compost levels (ton/fed) (A) } \\
\hline & \multicolumn{5}{|c|}{$1^{\text {st }}$ season $(2012 / 2013)$} & \multicolumn{5}{|c|}{$2^{\text {nd }}$ season $(2013 / 2014)$} \\
\hline & 0.0 & 2.5 & 5.0 & 7.5 & $\begin{array}{l}\text { Mean } \\
\text { (B) }\end{array}$ & 0.0 & 2.5 & 5.0 & 7.5 & $\begin{array}{l}\text { Mean } \\
\text { (B) }\end{array}$ \\
\hline \multicolumn{11}{|c|}{ Chlorophyll a } \\
\hline Control & 1.162 & 1.170 & 1.246 & 1.261 & 1.210 & 1.220 & 1.227 & 1.262 & 1.397 & 1.276 \\
\hline Sal. at $100 \mathrm{ppm}$ & 1.228 & 1.271 & 1.283 & 1.262 & 1.261 & 1.194 & 1.265 & 1.405 & 1.381 & 1.311 \\
\hline Sal. at $200 \mathrm{ppm}$ & 1.325 & 1.415 & 1.263 & 1.405 & 1.352 & 1.252 & 1.264 & 1.410 & 1.331 & 1.314 \\
\hline Asc. at $100 \mathrm{ppm}$ & 1.243 & 1.257 & 1.200 & 1.251 & 1.238 & 1.334 & 1.326 & 1.291 & 1.308 & 1.310 \\
\hline Asc. at $200 \mathrm{ppm}$ & 1.283 & 1.381 & 1.406 & 1.305 & 1.344 & 1.314 & 1.273 & 1.330 & 1.360 & 1.319 \\
\hline Active yeast at $5 \mathrm{~g} / \mathrm{l}$ & 1.157 & 1.232 & 1.148 & 1.304 & 1.210 & 1.081 & 1.095 & 1.213 & 1.423 & 1.203 \\
\hline Active yeast at $10 \mathrm{~g} / \mathrm{l}$ & 1.153 & 1.229 & 1.364 & 1.505 & 1.313 & 1.226 & 1.427 & 1.394 & 1.302 & 1.337 \\
\hline Vit. E at $50 \mathrm{ppm}$ & 1.261 & 1.210 & 1.302 & 1.231 & 1.251 & 1.238 & 1.188 & 1.228 & 1.232 & 1.222 \\
\hline Vit. E a & 1.194 & 1.217 & 1.302 & 1.233 & 1.236 & 1.260 & 1.397 & 1.387 & 1.427 & 1.368 \\
\hline Mean (A & 1.223 & 1.265 & 1.279 & 1.306 & & 1.213 & 1.251 & 1.313 & 1.340 & \\
\hline L.S.D. at $5 \%$ & \multicolumn{2}{|c|}{$\mathrm{A}=0.014$} & $\mathrm{~B}=0.041$ & \multicolumn{2}{|c|}{$\mathrm{AB}=0.082$} & \multicolumn{2}{|c|}{$\mathrm{A}=0.027$} & $\mathrm{~B}=0.034$ & \multicolumn{2}{|c|}{$\mathrm{AB}=0.068$} \\
\hline \multicolumn{11}{|c|}{ Chlorophyll b } \\
\hline Control & 0.444 & 0.496 & 0.506 & 0.438 & 0.471 & 0.490 & 0.430 & 0.447 & 0.497 & 0.466 \\
\hline Sal. at $100 \mathrm{ppm}$ & 0.454 & 0.461 & 0.561 & 0.526 & 0.500 & 0.452 & 0.453 & 0.587 & 0.530 & 0.506 \\
\hline Sal. at 200 ppm & 0.471 & 0.568 & 0.487 & 0.562 & 0.522 & 0.474 & 0.513 & 0.571 & 0.623 & 0.545 \\
\hline Asc. at $100 \mathrm{ppm}$ & 0.477 & 0.418 & 0.514 & 0.595 & 0.501 & 0.417 & 0.557 & 0.499 & 0.498 & 0.493 \\
\hline Asc. at 2 & 0.613 & 0.516 & 0.527 & 0.551 & 0.552 & 0.464 & 0.525 & 0.531 & 0.511 & 0.508 \\
\hline Active yeast at $5 \mathrm{~g} / \mathrm{l}$ & 0.424 & 0.471 & 0.514 & 0.613 & 0.506 & 0.473 & 0.435 & 0.485 & 0.580 & 0.493 \\
\hline Active yeast at $10 \mathrm{~g} / \mathrm{l}$ & 0.501 & 0.499 & 0.520 & 0.638 & 0.539 & 0.513 & 0.520 & 0.595 & 0.540 & 0.542 \\
\hline Vit. E at $50 \mathrm{ppm}$ & 0.464 & 0.472 & 0.519 & 0.559 & 0.504 & 0.475 & 0.525 & 0.498 & 0.517 & 0.504 \\
\hline Vit. E : & 0.434 & 0.454 & 0.529 & 0.697 & 0.529 & 0.444 & 0.517 & 0.502 & 0.545 & 0.502 \\
\hline Mean & 0.476 & 0.484 & 0.520 & 0.575 & & 0.467 & 0.497 & 0.524 & 0.538 & \\
\hline $5 \%$ & \multicolumn{2}{|c|}{$\mathrm{A}=0.011$} & $\mathrm{~B}=0.030$ & \multicolumn{2}{|c|}{$\mathrm{AB}=0.060$} & \multicolumn{2}{|c|}{$\mathrm{A}=0.015$} & $\mathrm{~B}=0.025$ & \multicolumn{2}{|c|}{$\mathrm{AB}=0.050$} \\
\hline \multicolumn{11}{|c|}{ Carotenoids } \\
\hline Control & 0.417 & 0.477 & 0.462 & 0.580 & 0.484 & 0.433 & 0.510 & 0.569 & 0.593 & 0.526 \\
\hline Sal. at $100 \mathrm{ppm}$ & 0.438 & 0.490 & 0.550 & 0.617 & 0.524 & 0.439 & 0.524 & 0.559 & 0.687 & 0.552 \\
\hline Sal. at $200 \mathrm{ppm}$ & 0.483 & 0.482 & 0.592 & 0.656 & 0.553 & 0.482 & 0.581 & 0.609 & 0.661 & 0.583 \\
\hline Asc. at $100 \mathrm{ppm}$ & 0.442 & 0.472 & 0.537 & 0.612 & 0.516 & 0.448 & 0.519 & 0.579 & 0.665 & 0.553 \\
\hline & 0.525 & 0.538 & 0.596 & 0.708 & 0.592 & 0.473 & 0.529 & 0.608 & 0.738 & 0.587 \\
\hline Active yeast at $5 \mathrm{~g} / \mathrm{l}$ & 0.475 & 0.471 & 0.643 & 0.619 & 0.552 & 0.435 & 0.514 & 0.563 & 0.674 & 0.546 \\
\hline Active yeast at $10 \mathrm{~g} / \mathrm{l}$ & 0.456 & 0.500 & 0.630 & 0.606 & 0.548 & 0.464 & 0.524 & 0.585 & 0.636 & 0.552 \\
\hline Vit. E at $50 \mathrm{ppm}$ & 0.444 & 0.467 & 0.551 & 0.592 & 0.513 & 0.442 & 0.496 & 0.580 & 0.628 & 0.537 \\
\hline Vit. E at 100 ppm & 0.470 & 0.501 & 0.544 & 0.608 & 0.531 & 0.459 & 0.529 & 0.564 & 0.682 & 0.559 \\
\hline Mean (A) & 0.461 & 0.489 & 0.567 & 0.622 & & 0.453 & 0.525 & 0.580 & 0.663 & \\
\hline L.S.D. at $5 \%$ & \multicolumn{2}{|c|}{$\mathrm{A}=0.014$} & $\mathrm{~B}=0.023$ & \multicolumn{2}{|c|}{$\mathrm{AB}=0.046$} & \multicolumn{2}{|c|}{$\mathrm{A}=0.027$} & $\mathrm{~B}=0.020$ & \multicolumn{2}{|c|}{$\mathrm{AB}=0.040$} \\
\hline
\end{tabular}

Sal. : Salicylic acid Asc. : Ascorbic acid Vit. E : Vitamin E 
the second season resulted in the highest contents of carotenoids. According to the obtained results, it can be concluded that spraying cumin plants with Sal. and Asc. has positive effects on chlorophyll ( $a$ and $b$ ) and carotenoids contents in cumin fresh leaves, these results may be attributed to the positive action of antioxidants in catching or chelating the free radicals while could be results in the regulation of several physiological process in plants such as photosynthesis, enhanced the activity of chlorophyllas enzymes while resulted in appearance of colored pigments (Moor, 1979). The role of salicylic acid in enhancing pigments was found by Al-Shewailly (2012) on cumin and Botros (2013) on caraway, while Singh et al. (2001) on senna and ElLeithy et al. (2011) on geranium concluded that ascorbic acid have positive effect on pigments. Also, yeast is considered as a natural source of cytokinns that stimulate the synthesis of proteins, nucleic acid and chlorophyll (Fathy and Farid, 1996). Our results are in some direction with that of AlDoghachi et al. (2012) on cumin and Eid and Kassem (2009) on Calendula officinalis.

The interaction between main and sub plots $(\mathrm{A} \times \mathrm{B})$ treatments was significant for chlorophyll $\mathrm{a}, \mathrm{b}$ and carotenoids in both seasons (Table 2). The highest contents of chl. a were obtained with compost (7.5) on combination with active yeast $(10 \mathrm{~g} / 1)$ in the first season or with vit. E (100 ppm) in the second season. While, the highest contents of chl. b were obtained by compost (7.5 ton/fed) with active yeast $(10 \mathrm{~g} / \mathrm{l})$ in both seasons and with vit. $\mathrm{E}(100 \mathrm{ppm})$ in the first season. While, the interaction treatments of compost (7.5 ton/fed) plus Asc. (200 ppm), in both seasons resulted to the highest contents of carotenoids.

\section{b. $\mathrm{N}, \mathrm{P}$ and $\mathrm{K} \%$ :}

Data presented in Table (3) indicated that all used compost levels significantly increased $\mathrm{N}, \mathrm{P}$ and $\mathrm{K} \%$ in the dry leaves of cumin comparing with control. The highest percentages were obtained with high level of compost ( 7.5 ton/fed). Organic fertilizer may improve the use efficiency of essential elements. Also, organic manure may be attracted and held nutrients and water ion its surface to supply the plants with suitable amounts for a longer time. Similar results were obtained by Shalatet (2006) on cumin and Ali et al. (2010) on anise.

Regarding to bio-stimulant treatments, all used eight treatments significantly increased $\mathrm{N}, \mathrm{P}$ and $\mathrm{K} \%$, in both seasons, with comparing to control, except, the treatment of active yeast $(5 \mathrm{~g} / \mathrm{l})$ for phosphorus in the first seasons (Table 3). Regarding to $\mathrm{N} \%$, the highest percentages were obtained with Sal. (200 ppm) in both seasons and vit. E (100 ppm) in the second season. Concerning to $\mathrm{P}$ and $\mathrm{K} \%$, the highest values were obtained by Sal. (200 ppm) in both seasons. This result might be due to the fact that bio-stimulants enhance the uptake of mineral element by plant roots through the root zone which have available forms of mineral nutrients as a result of adding organic manure. Similar results were found in many plants such as Tagetes minuta (Ali, 2004) and coriander (Rekaby, 2013) regarding salicylic acid, on snap bean (Nour et al., 2012) regarding to vit. E. While Attia and Moftah (2002) on borage and Eid et al. (2011) on Tagetes erecta and Ali (2004) on Tagetes minuta and coriander (Rekaby, 2013) regarding to salicylic acid on snap bean (Nour et al., 2012) Regarding vit. E. While, Attia and Moftah (2002) on borage and Eid et al. (2011) on Tagetes erecta found that application of ascorbic acid increased N, P and K. Moreover, Eid and Kassem (2009) on Calendula officinalis and Abdou et al. (2013) on black cumin mentioned that active yeast at $10 \mathrm{~g} / \mathrm{l}$ treatment resulted the highest percentages of $\mathrm{N}, \mathrm{P}$ and $\mathrm{K}$.

The interaction between main and sub plots $(\mathrm{A} \times \mathrm{B})$ was significant for $\mathrm{N}, \mathrm{P}$ and $\mathrm{K}$ $\%$ in both seasons. The highest values of $\mathrm{N}$, $\mathrm{P}$ and $\mathrm{K} \%$ were obtained due to compost (7.5 ton/fed) in combination with Sal. (200 ppm) in both seasons and compost (7.5 
Table 3. Effect of compost, salicylic acid, ascorbic acid, active yeast and vitamin $\mathbf{E}$ on $\mathbf{N}$, $P$ and $K$ percentages of Cuminum cyminum, $L$., at the first and second seasons.

\begin{tabular}{|c|c|c|c|c|c|c|c|c|c|c|}
\hline \multirow{3}{*}{$\begin{array}{l}\text { Bio-stimulant } \\
\text { treatments (B) }\end{array}$} & \multicolumn{10}{|c|}{ Compost levels (ton/fed) (A) } \\
\hline & \multicolumn{5}{|c|}{$1^{\text {st }}$ season $(2012 / 2013)$} & \multicolumn{5}{|c|}{$2^{\text {nd }}$ season $(2013 / 2014)$} \\
\hline & 0.0 & 2.5 & 5.0 & 7.5 & $\begin{array}{c}\text { Mean } \\
\text { (B) }\end{array}$ & 0.0 & 2.5 & 5.0 & 7.5 & $\begin{array}{c}\text { Mean } \\
\text { (B) }\end{array}$ \\
\hline \multicolumn{11}{|c|}{$\mathrm{N} \%$} \\
\hline Control & 1.30 & 1.30 & 1.34 & 1.56 & 1.38 & 1.34 & 1.41 & 1.55 & 1.60 & 1.48 \\
\hline Sal. at 100 ppm & 1.33 & 1.40 & 1.61 & 1.70 & 1.51 & 1.35 & 1.50 & 1.60 & 1.72 & 1.54 \\
\hline Sal. at 200 ppm & 1.41 & 1.59 & 1.71 & 1.83 & 1.64 & 1.42 & 1.53 & 1.61 & 1.77 & 1.58 \\
\hline Asc. at $100 \mathrm{ppm}$ & 1.42 & 1.47 & 1.52 & 1.62 & 1.51 & 1.37 & 1.44 & 1.59 & 1.67 & 1.52 \\
\hline Asc. at $200 \mathrm{ppm}$ & 1.45 & 1.55 & 1.49 & 1.67 & 1.54 & 1.46 & 1.51 & 1.57 & 1.74 & 1.57 \\
\hline Active yeast at $5 \mathrm{~g} / \mathrm{l}$ & 1.37 & 1.40 & 1.45 & 1.60 & 1.46 & 1.44 & 1.50 & 1.58 & 1.65 & 1.54 \\
\hline Active yeast at $10 \mathrm{~g} / \mathrm{l}$ & 1.38 & 1.44 & 1.62 & 1.61 & 1.51 & 1.47 & 1.52 & 1.58 & 1.65 & 1.56 \\
\hline Vit. E at 50 ppm & 1.46 & 1.41 & 1.52 & 1.58 & 1.49 & 1.53 & 1.50 & 1.59 & 1.65 & 1.57 \\
\hline Vit. E at $100 \mathrm{ppm}$ & 1.44 & 1.43 & 1.53 & 1.60 & 1.50 & 1.50 & 1.55 & 1.60 & 1.69 & 1.59 \\
\hline Mean (A) & 1.40 & 1.44 & 1.54 & 1.64 & & 1.43 & 1.50 & 1.59 & 1.69 & \\
\hline L.S.D. at $5 \%$ & \multicolumn{2}{|c|}{$\mathrm{A}=0.04$} & $\mathrm{~B}=0.06$ & \multicolumn{2}{|c|}{$\mathrm{AB}=0.12$} & \multicolumn{2}{|c|}{$\mathrm{A}=0.05$} & $\mathrm{~B}=0.04$ & \multicolumn{2}{|c|}{$\mathrm{AB}=0.08$} \\
\hline \multicolumn{11}{|c|}{$\mathbf{P} \%$} \\
\hline Control & 0.195 & 0.214 & 0.238 & 0.241 & 0.222 & 0.197 & 0.218 & 0.236 & 0.250 & 0.225 \\
\hline Sal. at 100 ppm & 0.191 & 0.211 & 0.247 & 0.260 & 0.227 & 0.206 & 0.226 & 0.245 & 0.270 & 0.237 \\
\hline Sal. at 200 ppm & 0.214 & 0.234 & 0.259 & 0.287 & 0.249 & 0.214 & 0.242 & 0.263 & 0.341 & 0.265 \\
\hline Asc. at $100 \mathrm{ppm}$ & 0.203 & 0.226 & 0.238 & 0.262 & 0.232 & 0.208 & 0.227 & 0.262 & 0.275 & 0.243 \\
\hline Asc. at $200 \mathrm{ppm}$ & 0.224 & 0.235 & 0.249 & 0.262 & 0.242 & 0.226 & 0.243 & 0.257 & 0.294 & 0.255 \\
\hline Active yeast at $5 \mathrm{~g} / \mathrm{l}$ & 0.201 & 0.221 & 0.224 & 0.251 & 0.224 & 0.213 & 0.221 & 0.244 & 0.285 & 0.241 \\
\hline Active yeast at $10 \mathrm{~g} / \mathrm{l}$ & 0.209 & 0.227 & 0.245 & 0.253 & 0.233 & 0.231 & 0.239 & 0.248 & 0.263 & 0.245 \\
\hline Vit. E at 50 ppm & 0.199 & 0.229 & 0.232 & 0.263 & 0.231 & 0.207 & 0.225 & 0.240 & 0.257 & 0.232 \\
\hline Vit. E at $100 \mathrm{ppm}$ & 0.210 & 0.226 & 0.235 & 0.262 & 0.233 & 0.211 & 0.225 & 0.246 & 0.271 & 0.238 \\
\hline Mean (A) & 0.205 & 0.225 & 0.241 & 0.260 & & 0.213 & 0.230 & 0.249 & 0.279 & \\
\hline L.S.D. at $5 \%$ & \multicolumn{2}{|c|}{$\mathrm{A}=0.008$} & $\mathrm{~B}=0.005$ & \multicolumn{2}{|c|}{$\mathrm{AB}=0.010$} & \multicolumn{2}{|c|}{$\mathrm{A}=0.004$} & $\mathrm{~B}=0.007$ & \multicolumn{2}{|c|}{$\mathrm{AB}=0.014$} \\
\hline \multicolumn{11}{|c|}{ K\% } \\
\hline Control & 1.16 & 1.19 & 1.28 & 1.36 & 1.25 & 1.19 & 1.26 & 1.32 & 1.43 & 1.30 \\
\hline Sal. at 100 ppm & 1.25 & 1.30 & 1.36 & 1.45 & 1.34 & 1.21 & 1.30 & 1.35 & 1.51 & 1.34 \\
\hline Sal. at $200 \mathrm{ppm}$ & 1.36 & 1.38 & 1.45 & 1.59 & 1.45 & 1.40 & 1.37 & 1.43 & 1.62 & 1.46 \\
\hline Asc. at $100 \mathrm{ppm}$ & 1.21 & 1.34 & 1.37 & 1.46 & 1.35 & 1.27 & 1.32 & 1.36 & 1.47 & 1.36 \\
\hline Asc. at $200 \mathrm{ppm}$ & 1.31 & 1.35 & 1.39 & 1.48 & 1.38 & 1.37 & 1.40 & 1.40 & 1.47 & 1.41 \\
\hline Active yeast at $5 \mathrm{~g} / \mathrm{l}$ & 1.18 & 1.26 & 1.31 & 1.41 & 1.29 & 1.22 & 1.31 & 1.38 & 1.52 & 1.36 \\
\hline Active yeast at $10 \mathrm{~g} / \mathrm{l}$ & 1.22 & 1.35 & 1.38 & 1.50 & 1.36 & 1.25 & 1.36 & 1.43 & 1.50 & 1.39 \\
\hline Vit. E at 50 ppm & 1.21 & 1.32 & 1.35 & 1.45 & 1.33 & 1.20 & 1.36 & 1.37 & 1.52 & 1.36 \\
\hline Vit. E at $100 \mathrm{ppm}$ & 1.16 & 1.36 & 1.38 & 1.44 & 1.34 & 1.24 & 1.34 & 1.39 & 1.53 & 1.38 \\
\hline Mean (A) & 1.23 & 1.32 & 1.36 & 1.46 & & 1.26 & 1.34 & 1.38 & 1.52 & \\
\hline L.S.D. at $5 \%$ & \multicolumn{2}{|c|}{$\mathrm{A}=0.05$} & $\mathrm{~B}=0.04$ & \multicolumn{2}{|c|}{$\mathrm{AB}=0.08$} & \multicolumn{2}{|c|}{$\mathrm{A}=0.06$} & $\mathrm{~B}=0.04$ & \multicolumn{2}{|c|}{$\mathrm{AB}=0.08$} \\
\hline
\end{tabular}

Sal. : Salicylic acid Asc. : Ascorbic acid Vit. E : Vitamin E 
ton $/$ fed $) \times$ vit. $\mathrm{E}(100 \mathrm{ppm})$ for $\mathrm{K} \%$ or compost $(7.5$ ton $/ \mathrm{fed}) \times$ Asc. $(200 \mathrm{ppm})$ for $\mathrm{N} \%$ in the second season.

\section{RECOMMENDATIONS}

It recommended that supplying cumin plants with compost at 7.5 ton/fed and treating plants with salicylic acid or ascorbic acid, each at $200 \mathrm{ppm}$ to obtained the maximum essential oil yield.

\section{REFERENCES}

Abdou, M.A.H.; Aly, M.K.; Attia, F.A.; Ahmed, E.T. and Al-Shareif, A.M.O. (2013). Physiological studies on black cumin plant. The $1^{\text {st }}$ Under Press Inter of Hort. Agric. Assuit, February 2013.

Abdou, M.A.H.; Attia, F.A.; Ahmed, E.T. and Abd El-Naeem, L. (2009). Response of caraway plants to some organic, antioxidants and biofertilization treatments. Proc. $4^{\text {th }}$ Inter. Environ. Conf., Mansoura Univ. on Environmental and Healthy Safety, p: 109-119.

Al-Doghachi, E.H.A.; Hamza, R.K. and Essa, W.M. (2012). Physiological study of the effect spraying with seaweed extracts and addition methods of active dry yeast on vegetative and flowering growth of Cumin plant (Cuminum cyminum, L) . Basrah J. Agric. Sci., 25(1):1-12.

Ali, A.F. (2004). The benefits of using some natural sources of phosphate and salicylic acid on Tagetes minuta, L. plants, Minia J. of Agric. Res. Develop., 24(4):621648.

Ali, F.S.; Zayed, G.; Saad, O.A. and AbdulMohsen (2010). The effects of compost and inoculation with mycorrhizae on anise plant growth. Minia $2^{\text {nd }}$ Conf. Agric. \& Environ. Sci. Agric. and Develop. Scopes. March 22-24, 2010, 509-515. Minia Univ., Egypt.

Al-Shareif, A.M.O. (2006). Response of Caraway Plants Grown in Sandy Soil Under Drip Irrigation System to Some
Biofertilization and Antioxidant Treatments. M.Sc. Thesis., Fac. Agric., Minia Univ., Egypt.

Al-Shareif, A.M.O. (2012). Physiological Studies on Black Cumin Plant. Ph.D. Thesis., Fac. Agric., Minia Univ., Egypt.

Al-Shewailly, M. SH.R. (2012). Physiological study of the effect planting method and number of plant in hole and spraying of salicylic acid in vegetative and growth of cumin plant (Cuminum cyminum, L.). Basrah Journal of Agricultural Sciences, 25(2):37-46.

Amin, I.S. and Abdel Wahab, M.A. (1999). Effect of chemical fertilization on Cuminum cyminum, L. plants under North Sinai conditions. Desert Inst. Bull., Egypt., 48(1):1-19.

Asgharipour, M.R. and Sirousmehr, A.R. (2012). Comparison of three techniques for estimating phytotoxicity in municipal solid waste compost. Annals of Biological Research, 3(2):1094-1101.

Asl, S.G and Moosavi, S.S. (2012). A Study and Evaluation in organic Fertilizers' Effects on Seed Yield and Some Main Agricultural Characteristics on Cumin plant Ardabil Region Conditions. Annals of Biological Research, 3(11):5130-5132.

Attia, F.A. and Moftah, A.E. (2002). Response of lead-polluted Borage (Borago officinalis, L.) to antioxidant treatments. J. Agric. Sci. Mansoura Univ., 27(6):4063-4082 .

Ayat, A.M. (2007). Effect of Fertilization With Macro, Micro Nutrients and Antioxidants on Coriander (Coriandrum sativum, L.) Plants Grown in New Reclaimed Land. M.Sc. Thesis, Fac. Agric., Minia Univ., Egypt.

Badran, F.S.; Attia. F.A. and Ayat, A.M. (2013). Effect of macro/micro fertilization treatments, as well as, salicylic and ascorbic acids on growth, fruit yield and essential oil of coriander. Plants grown in sandy soil. The first 
Assuit Inter. Conf. of Horticulture, 24$27^{\text {th }}$ Feb., 2013.

Badran, F.S.; Aly, M.K.; Hassan, E.A. and Shalaltet, Sh.G. (2007). Effect of organic and biofertilization treatments on cumin plants, The third conf. of Sustainable Agric. Dev., Fayoum, Egypt, Nov. 12-14, 2007: 371-380.

Botros, W.S.E. (2013). Physiological Studies on Caraway Plants. M.Sc. Thesis, Fac. Agric., Minia Univ., Egypt.

British Pharmacopoeia (1963). Determination of volatile oil drugs. The Pharmaceutical Press, London.

Chapman, H.D. and Pratt, P.F. (1975). Methods of Analysis for Soil, Plant and Water Calif. Univ. Division of Agric. Sci., 172-174.

Cottenie, A.; Verloo, M.; Velghe, M. and Camerlynck, R. (1982). Chemical Analysis of Plant and Soil. Laboratory of Analytical and Agro Chemistry. State Univ., Ghent, Belgium.

Eid, M.I. and Kassem, A.H.M. (2009). Effect of phosphorein and active dry yeast on Calendulla officinalis, L. J. Product and Dev., 14(2):491-505.

Eid, R.A.; Taha, L.S. and Ibrahiem, S.M.M (2011). Alleviation of adverse effects of salinity on growth and chemical constituents of marigold plants by using glutathione and ascorbate. J. Appl. Sci. Res., 7(5):714-721.

El-Leithy, S.; Ayad, H. and Reda, F. (2011). Effect of riboflavin, ascorbic acid and dry yeast on vegetative growth, essential oil pattern and antioxidant activity of geranium (Pelargonium graveolens, L.). American-Eurasian J. Agric. and Enveron. Sci., 10(5):781-786.

Fathy, E.S.L. and Farid, S. (1996). The possibility of using vitamin $\mathrm{B}_{5}$ and yeast to delay senescence and improve growth and yield of common beans (Phaseolus vulgaris, L.). J. Agric. Sci. Mansoura Univ., 121 (4):1415-1423.
Forouzandeh, M.; Karimian, M.A. and Mohkami, Z. (2014). Effect of water stress and different types of organic fertilizers on essential oil content and yield components of Cuminum cyminum. Indian Journal of Fundamental and Applied Life Sciences, 4(3):533-536.

Hassan, E.A. and Ali, E.F. (2010). Response of Coriandrum sativum, L. plants to cutting, as well as, glycine and salicylic acid treatments. Minia J. of Agric. Res. \& Dev., 30(1):15-29.

Hemdan, S.H.O. (2008). Effect of Some Organic and Biofertilization Treatments on Anise Plants. M.Sc. Thesis, Fac. Agric., Minia Univ., Egypt.

Hendawy, S.F. (2008). Comparative study of organic and mineral fertilization on Pantago arvenaria plant. J. Appl. Sci. Res., 4(5):500-506.

Hendawy, S.F. and Ezz El-Din, A.A. (2010). Growth and yield of Foeniculum vulgare var. azoricum as influenced by some vitamins and amino acids. Ozean Journal of Applied Sciences, 3(1):113-123.

Ismail, S.I.I. (2008). Anatomical and Physiological Studies on Nigella sativa, L. Plant. Ph.D. Thesis., Fac. Agric., Mansoura Univ., Egypt.

Marculesuca, A.; Sand, C.; Barbu, C.H., Babit, D. and Hanganu, D. (2002). Possibilities of influencing the biosynthesis and accumulation of the active principles in Chrysanthemum balsamita, L. Species Roum. Biotech. Lett., 7(1):548-577.

Marzok, Z.S.A. (2011). Physiological Studies on Basil Plant. M.Sc. Thesis, Fac. Agric., Mansoura Univ., Egypt.

Moor, T.C. (1979). Biochemistry and Physiology of plant Hormones. Springer Verlage, New York, U.S.A. pp: 274.

Moran, R. (1982). Formula determination of chlorophylls Pigments extracted with N$\mathrm{N}$ dimethyl-formamide. Plant Physiological., 69 : 1376-1381. 
MSTAT-C (1986). A Microcomputer Program for the Design, Management and Analysis of Agronomic Research Experiments (Version 4.0), Michigan Stat Univ., U.S.

Nour, K.A.M.; Mansour, N.T.S. and Eisa, G.S.A. (2012). Effect of some antioxidants on some physiological and anatomical characters of snap bean plants under sandy soil conditions. New York Sci. J., 5(5):1-9.

Ozeker, E. (2005). Salicylic acid and its effects on plants. EU. Faculty of Agriculture J., 42(1):213-223.

Patel, N.D.; Patel, Y.B. and Mankad, A.U. (2013). Evaluating growth and development of Cuminum cyminum, L. under different fertigations. International Journal of Pharmacy and Life Science, 5(11):3977-3981.

Rahimi, A.R.; Rokhzadi, A.; Amini, S. and Karami, E. (2013). Effect of salicylic acid and methyl jasmonate on growth and secondary metabolites in Cuminum cyminum, L. Journal of Biodiversity and Environmental Sciences, 3(12):140-149.

Rao, M.V.; Koch, R. and Davis, K.R. (2000). Ozone a tool for Probing programmed cell death in plants. Plant Mol. Biol., 44(3):346-358.

Rekaby, A.M. (2013). Improving The Productively of Coriander Plants by The Use of Some Unconventional Treatments. Ph.D. Thesis, Fac. Agric., Minia Univ., Egypt.

Saeidnezhad, A.M. and RezvaniMoghadum, P. (2009). The effect of biological and chemical fertilizer on morphological properties, yield and yield components of cumin. Journal of Horticultural Science, 24(1):14-38.
Safwat, M.S. and Badran, F.S (2002). Efficiency of organic and bio-fertilizers, in comparison with chemical fertilization on growth, yield and essential oil of cumin plants. The $9^{\text {th }}$ Conf. of Medicinal and Aromatic plants, Cairo, Egypt.

Seghatoleslami, M. (2013). Effect of water stress, bio-fertilizer and manure on seed and essential oil yield and some morphological traits of cumin, Bulgarian Journal of Agricultural Science, 19(6):1268-1274.

Shala, A.Y. E. (2012). Response of Foeniculum vulgare, Mill. and Carum carvi, L. to NPK and Ascorbic and Salicylic Acids Treatments. Ph.D. Thesis, Fac. Agric., Kafr El-Sheikh Univ., Egypt.

Shalatet, Sh.G. (2006). Comparative Studies on Cumin Productivity Grown Under Traditional and Organic Cultivation Systems. M.Sc. Thesis, Fac. Agric., Minia Univ., Egypt.

Singh, D.V.; Srivastava, G.C. and Abdin, M.Z. (2001). Amelioration of negative effect of water stress in Cassia angustifolia by benzyladenine and / or ascorbic acid. Biologia Plantarum, 44(1):141-143.

Tanious, C.T.S. (2008). Effect of Some Organic Fertilization Treatments on Fennel Plants. M.Sc. Thesis, Fac. Agric., Minia Univ., Egypt.

Wilde, S.A. ; Covey, R.P.; Lyer, J.C. and Voigt, G.K. (1985). Soil and Plant Analysis for Tree Culture. Oxford, IBH. Publishing Co., New Delhi, India. 


\section{M.A.H. Abdou et al.}

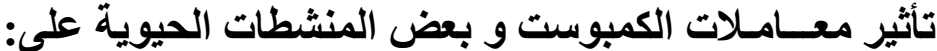 ب. إنتاج الزيت الطيار وبعض المكونات الكيماوية لنباتات الكمون الكئ}

محمود عبد الهادي حسن عبده و محمد كمال عبد العال علي و أحمد عبد المنعم السيد و عماد الدين توفيق أحمد و طارق عبد الناصر حلمي و الزعدي قسم البساتين، كلية الزر اعة، جامعة المنيا، مصر.

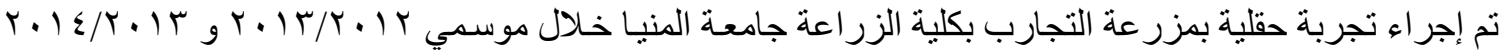

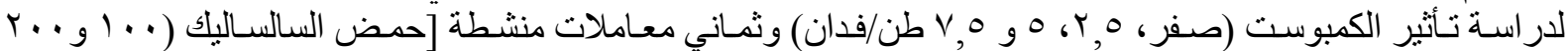

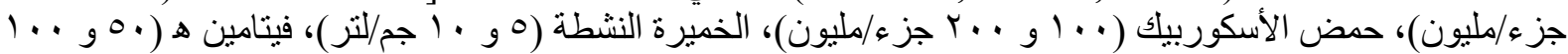

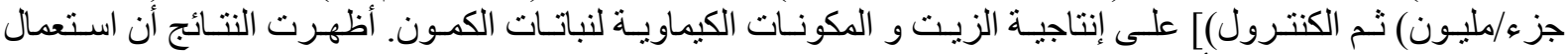

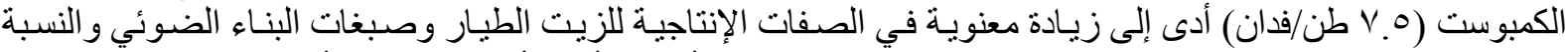

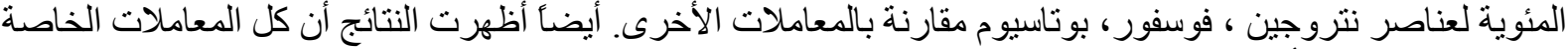

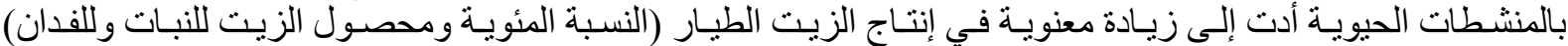

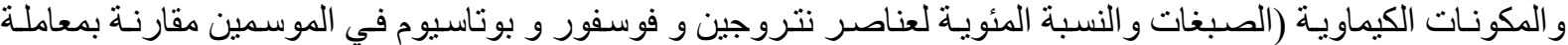

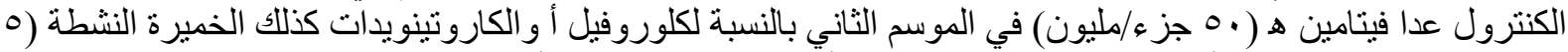

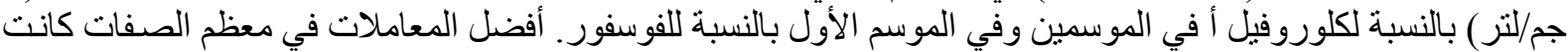

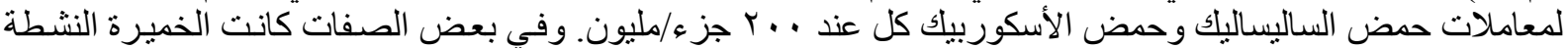

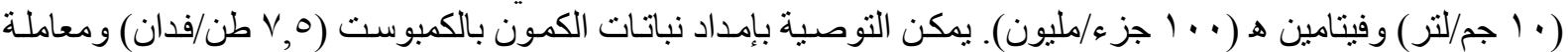

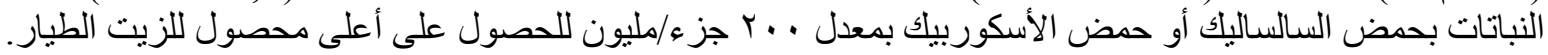

